\title{
WHAT ARE THE USAGE CONDITIONS OF WEB 2.0 TOOLS FACULTY OF EDUCATION STUDENTS?
}

\author{
Ahmet AGIR \\ Hasan Ali Yucel Educational Faculty \\ Department of Computer Education \\ and Instructional Technology \\ Istanbul University, Istanbul, TURKEY
}

\section{ABSTRACT}

As a result of advances in technology and then the emergence of using Internet in every step of life, web that provides access to the documents such as picture, audio, animation and text in Internet started to be used. At first, web consists of only visual and text pages that couldn't enable to make user's interaction. However, it is seen that not only access to information but also analyzing, configuring, sharing information and creating new information came into the prominence in 21st century. Changing needs and conditions has led to the changing web and the emergence of Web 2.0.

The purpose of the study is to be examined faculty of education students' the usage condition of Web $\mathbf{2 . 0}$ tools in terms of various variables.

This is a descriptive style study with a survey model that aims to present faculty of education students' the usage condition of Web 2.0 tools. The population of research composed of $\mathbf{3 5 9}$ students who study at first grade of Faculty of Education in Istanbul University in 2008-2009 academic year. These students were taken from eight different departments through random sampling for this research. The data collection used in this research was a questionnaire that is developed by researcher with 18 items. One-way ANOVA, t-test, was made to determine whether there was a significant different between averages according to the varieties about individual properties. It is seen in analyses which were practiced in line with this aim that faculty of education students' the usage condition of Web 2.0 tools differentiates in terms of departments, gender, high school which they graduate, the year of Internet and computer usage, weekly average duration of Internet and computer usage.

It can be generally said that faculty of education students don't use Web 2.0 applications in the expected level. It is very important that pre-service teachers should learn how to use these tools as well as they should receive education of computer literacy in the faculty of education which trains teachers. The other suggestion is that these tools should be integrated with courses which pre-service teachers receive in the prevocational training. Different samples can be chosen or sample can be enlarged in the further researches. As comparison can be made between students of different faculties, analyses can be thoroughly made by being benefited from qualitative research method. 


\section{INTRODUCTION}

After the Internet which is used in every step of life came up as a result of developments in technology, web which provides access to documents such as picture, sound, animation, text has begun to be used.

In the beginning, it comprised pages which are only visual, include text and don't allow user interaction.

But in the beginning of $21^{\text {st }}$ century, it is seen that abilities such as knowledge analysis, knowledge configuration as to necessity, forming new knowledge and sharing this knowledge have come into prominence.

Changing necessities and conditions lead to change web technology and come up WEB 2.0. O'Reilly (2005) states that web 2.0 is a revolution coming up in the information industry and describes it as second generation Internet services, social networks, folksonomy, wikis, other communication tools in other words the Internet is a system which users create and share each other.

D'Souza (2006) states that Web 2.0 is both readable and writable web and also indicates that it is not a programming language or software; it is a new web flow representing idea and technology.

Agir (2010) conformably indicates that Web 2.0 doesn't represent an existing technology but describes a phenomenon which is amorphous and combination of many technologies and designs.

He describes that it can provide users' participation, knowledge sharing, cooperation, collaborating and socialization; produce the web contents; organize existing contents; is user-centered Internet applications and contexts (Agir, 2010; Anderson, 2007; Beldarrin, 2006; Dearstyne, 2007; Deperlioğlu \& Köse, 2010; Kapp \& O' Driscoll, 2010; Li \& Pitts, 2009; McLoughlin \& Lee, 2007). Alexander (2006) conformably thinks that users play an active and fundamental role in the information architecture at present.

The Differences Between Web 1.0 and Web 2.0

Web 1.0 with which users only see the content and don't interfere in the contents is abandoned and web $\mathbf{2 . 0}$ which users are not only readers and can make share by both reading and writing the contents and provides interactive contents begin to be used (McLoughlin \& Lee, 2007).

While users display only the static contents in 1.0, users interact with the dynamic contents and share the contents, which they want, with the entire world without any knowledge of programmable language (Kapp \& Driscoll, 2010; Solomon \& Schrum, 2007).

Franklin and Harmelen (2007) indicate that idea exchange and cooperation become easier with this share. Table 1, in which the differences web 1.0 and 2.0 are presented, are given. 
Table: 1

The Differences Web 1.0 and 2.0 (O'Reilly, 2005)

\begin{tabular}{ll}
\hline Web 1.0 & Web 2.0 \\
\hline DoubleClick & Google AdSense \\
Ofoto & Flickr \\
Akamai & BitTorrent \\
mp3.com & Napster \\
Britannica Online & Wikipedia \\
personal websites & Blogging \\
Evite & upcoming.org and EVDB \\
domain name speculation & search engine optimization \\
page views & cost per click \\
screen scraping & web services \\
publishing & Participation \\
content management systems & Wikis \\
directories (taxonomy) & tagging ("folksonomy") \\
stickiness & syndication \\
\hline
\end{tabular}

Web 2.0 Tools

Web 2.0 tools consist of tools such as social networks, wikis, blogs, podcasts, video sharing sites, immediate communication tools, photograph sharing sites, joint study tools, social bookmarking tools, RSS. But in this part, social network, wikis, blogs and podcasts will be handled. Kapp and Driscoll (2010) indicate that web 2.0 tools make contribute to cooperative study of individuals and be used different web 2.0 tools in the educational field.

At the same time, Dudeney and Hockly (2007) indicate that primary web 2.0 tools which are used in the educational fields are wikis, podcasts and blogs.

Blogs. Blogs are web applications which easily enable individuals to share their thoughts, ideas, remarks, personal diaries with other people; can be easily formed and updated; enable readers to put their comments.

According to Wu (2006), blog which is formed with the combination of web and log words has also the meaning of writing to someone else's blog. According to other definition, blog is web pages which consist of writings which are reversely rowed on a page (Ebner, 2007; Kolari, Finin \& Joshi, 2006; Murugesan, 2007). It is required to state that blogs are different with their interactive side from normal web pages. Some writers define blogs as personal online diaries in addition to other facilities (Baggetun \& Wasson 2006; Glogoff, 2003).

According to Murugesan (2007), as blogs' inputs are text, some of them include photograph (photoblog or photolog), videos (videolog or vlog) or sounds (podcast). Writing in blog can be categorized as to their topics by being tagged. Tags which are given can be used as link. At the same time, blog writers can load various materials to their blogs from their cell phones (mob-blogging) (Anderson, 2007). Blogs can be used with many purposes in the educational aspect. Blogs especially enable students to express their opinion, learn cooperatively, reflect, create portfolio, think critically, develop their writing skill, participate actively and develop social skills and make contribution teachers and students to the learning environment. 
As blog can be easily formed and updated without technical information, it can be used in many education levels (Usluel \& Mazman, 2009). Williams and Jacobs (2004) emphasize that blogs are environments which make easier learning in the processes in higher education, is easily attuned to the learning environment and students easily express themselves. Besides, blogs are environments which writing skills are developed (Godwin, 2007; Johnson, 2004; Seitzinger, 2006; Tekinarslan, 2008), is provided active learning, teach the information literacy in the academician guidance and students can be received opinion from other students and their teachers. At time same time, blog provide critical thinking skill, cooperative study, feedback and active participation (Huffaker, 2005; Richardson, 2006). Besides, while students develop their own writing skills, they find opportunity to read and think writings which are written by other students. Thus, reflection is provided in communicative environment which is formed (Baggetun \& Wasson 2006; Kim, Hong, Bonk \& Lim, 2009; Moon, 2006; Perschbach, 2006). Students can be used them for developing portfolio (Beldarrain, 2006; Churchill, 2009; Grassley \& Bartoletti, 2009; Mansvelder-Longayroux, Beijard \& Verloop, 2007).

Besides, blogs enable students to express opinions and help them to develop social skills as well as blogs provide with skills such as critical thinking, writing, communicative learning, active learning (Ferdig \& Trammell, 2004; Kalelioğlu \& Gülbahar, 2010; Wang \& Fang, 2005). As a matter of the fact, the study which is conducted by Çuhadar and Kuzu (2006), Efimova (2004) support this thesis. Studies express that students who have difficulty in meeting other friends in the class environment can meet new friends by means of blog and blog has influence in being made new friends.

Wiki. Wikis are environments which are formed with communicative study and users can publish knowledge by arranging (Ferret, 2006). Wikis are named from the word wiki wiki (it means quick) in the Hawaii language, can connect to different Internet pages, are open-source software and are communicative environments in which everyone make writing, arrangement and publication without a technical information (Chao, 2007; Godwin-Jones, 2003). Wikis are simple but powerful cooperative authorship or content method system (Murugesan, 2007). The most known wiki application is Wikipedia. Wikipedia is shaped with especially young people's knowledge (Madden \& Fox, 2006). Wikipedia is sites which are arranged and formed encyclopedic knowledge with users' contribution (Alexander, 2006). Wikis are used for different purposes in the learning environment. The main ones are these: cooperative learning, learning based project, being shared documents such as schedule and course note, being made class discussion, being shared by being formed portfolio, dictionary and concept map.

Wikis enable students to play an active role in knowledge-based configuration (Boulos, Maramba \& Wheeler, 2006).

Dudeney and Hockly (2007) state that wikis have important roles such as they archive studies which are conducted and so the access to knowledge get easy, they enable students to share knowledge, a qualified learning environment forms with cooperation of teachers and students and they increase the interaction. Anderson (2007) and Safran, Helic and Gütl (2007) conformably indicate that wikis provide cooperative learning environment and wiki pages have traversed function which unchanged previous version of wiki pages can be examined and backspace function which enables previous pages to be restored in contradiction to blog pages. 
Grosseck (2009) indicates that wikis enable students and groups to cooperate in the student project, enable students to create portfolio, have qualification of help and discussion page for students and are an environment in which students can find references. Schwartz, Clark, Cossarin and Rudolph (2004) indicate that wikis are used in activities such as online dictionary usage, feedback and self-assessment, group projects, cooperative learning or questions which are frequently asked in the class.

Duffy and Bruns (2006) indicate that wikis can be used as a learning environment which students can develop their research projects, summarize about their readings and form cooperatively bibliography; instructors can publish resources such as schedule, course notes; students can arrange these documents and make comments; instructors can share opinions belonging to applications and documents belonging to this, form concept maps for brainstorming and give links to the concepts, make presentations for students; students can make comments about the presentations and make group work.

Schaffert et al. (2006) indicate that wikis can be used in activities such as project-based learning, cooperative writing stories and interdisciplinary and intercultural learning.

\section{Social Networks}

The Internet applications attain a dynamic structure and interaction increase by means of web 2.0 technology. This situation raise wish of being a member of groups and has influence in forming social networks (Carminati, Ferrari \& Perego, 2006). Social networks are applications which enable individual to create profile, communicate with family, friend and colleague and meet new friend and make plan (Lenhart \& Madden, 2007). It enables users to communicate aggregately with each other (Kapp \& Driscoll, 2010). Social networks consist of important features such as individual and group interaction, shared areas for cooperation, social relationship and information exchange in the webbased environment (Bartlett-Bragg, 2006).

The most known social networks are Facebook, Twitter, MySpace and etc. Social networks are software which offers various options for providing interaction between individuals and groups and helps to form social relationship (Onat \& Alikılıç, 2009). Social networks allow users to form groups by giving them opportunity of introducing themselves and their interests. It helps users who have common interests to find each other with connections and make more specific discussion by forming sub-groups (Franklin \& Harmelen, 2007). Social networks are used for many purposes in the education. It enables students and teachers to make online communicate with each other and share knowledge (Kapp \& Driscoll, 2010).

It is thought that social networks are environments which provide interactive, creative thinking and informal learning by means of free environment and opportunities which social networks offer (McLoughlin \& Lee, 2008). They are especially used in higher education for increasing interactive and group studies and making academician contact (Lenhart \& Madden, 2007). Agir (2010) put forward that creating a group for classes in especially universities in social networks and conveying messages to be conveyed with this way will be different and positive experience in terms of students and moreover, attaining recourses or announcements related to courses through social networks will be easier since students' usage time of technological tools increase at present. 
As social networks make easier cooperative learning and group studies, interaction between groups activates and all of group members can participate in the study. Besides, other usage purposes are thought to be shared knowledge resources and be provided feedback (Anderson, 2007).

As a result of Yuen and Yuen (2008)' studies, they indicate that social networks are used by students with the purposes of sharing digital media, sharing resources related to courses, asking questions in the direction of common opinions, making group studies and communicating with classmates. Kayıslı, Hazar and Oztürk (2011) found that social networks help students to consolidate subjects.

Podcast

Podcasts are digital sound program which are named from the words of iPod (portable music player) and broadcasting (publication) (Cych, 2006); are published and downloaded by people through RSSs; can be listened with both computer and digital sound tools(Petter, Reich \& Scheuermann, 2005). According to other definition, podcasts are sound records which speaking, discussing and lecturing are generally prepared in the MP3 format; can be listened with many devices from desktop to MP3 player (Anderson, 2007; Felix \& Stolarz, 2006; Patterson, 2006). Podcast and RSS are frequently used in the information literacy teaching and libraries (Godwin, 2007). According to Dudeney and Hockly (2007) and Agir (2010), podcast is a proper learning environment for the distance education. Materials which students and teachers need are prepared as visual or audial at short notice and required interaction and communication are provided by being conveyed to students in the long distance. Kentli and Polat (2010) indicate that instructors can use podcasts for reaching different type students and the usage of podcasts is an alternative way for the interaction with students outside traditional class environment for instructors. In addition, they state that the distance education becomes more interesting, creative and cooperative learning environment for students by using this technology. Safran, Helic and Gütl (2007) emphasize that podcast are frequently used in being distributed lesson contents and records in the education.

A different usage is to publish vocal and visual presentations and previous materials on wikis and blogs which are mentioned in the above (Horzum, 2010). Besides, podcasts are used in the education with the purposes of the preparation before lesson, listening lesson records which are missed, having resource about a topic. It has the opportunity of usage outside class for portable (Karaman, Yıldırım \& Kaban, 2008). Being easily portable shows that it can be used in the mobile learning (Gülseçen et al., 2010; Isık, Ozkaraca, Güler, 2010; Kaplan-Leiserson, 2005; Keskin, 2010; Mcgarr, 2009).

In this study, faculty of education students' usage condition of web $\mathbf{2 . 0}$ is examined in terms of various variables. In literature, a study directly related to subject of the study is not encountered. Faculty of education students' opinions about web 2.0 tools such as social networks, blogs and wikis, various studies which consist of their opinions related to usage in their professional life are chronologically presented. In the study of Saunders (2008), he indicates that pre-service teachers use Facebook for the purpose of creating a network belonging to teachers and cooperating. In the study of Altun (2008) which is carried out with 56 students who study in BOTE (Department of Computer Education and Instructional Technology)and are $4^{\text {th }}$ grade students, he research students' opinions and experiences related to wiki usage. 
It is seen that students overcome the difficulties which they have in the beginning and have some problems related to the content organization; they enter into wiki after process is over. This situation is interpreted as an indicator that they make an important stride in the manner of the application society. In the study of Karaman, Yıldırım and Kaban (2008) which is carried out with 33 students who study in Department of Computer Education and Instructional Technology and are $3^{\text {dh }}$ and $4^{\text {th }}$ grade students, they examine blogs special to groups and blogs opened in-class.

As a result of the study, it is seen that students support the usage of blogs and adopt more group blogs but participation is still low. Churchill (2009) researches the effect of blogs from web 2.0 tools on learning activities.

In the study, sample consists of 24 students who study in Information Technology Education, Hong Kong University.

It is observed that blogs which is used for access to course contents and class discussion have effect on learning and students gain experiences by reading, commenting/reading to other students' blogs.

In the study of Yang (2009) which is carried out with 43 students who study in Department of English Teaching, he researches the usage by pre-service English teachers in learning English. Blog environment which they can follow their own reflection processes.

It is examined that students include to which reflections by using blog environment. It is stated in the end that descriptive reflections are seen more than critical reflections and students have positive attitudes to blog usage, find easy to blog usage, are more comfortable and easier accessible than discussions which are practiced face to face and the learning environment become more comfortable and it is incentive.

In the study of Usluel, Mazman and Arıkan (2009) which is carried out with 162 students who study in Department of English Teaching and are $4^{\text {th }}$ grades, they research the usage condition of blog, wiki and Podcast.

At the end of study, it is stated that while the most known wiki application is Wikipedia, the least used application is Podcast. It is stated that pre-service English teachers' usage of Web 2.0 technologies is low in daily life.

In the study of Tekinarslan and Gürer'in (2011) which is carried out with 32 students who study in Department of Computer Education and Instructional Technology and are $2^{\text {nd }}$ grades, students' opinions about blog publication are handled.

At the end of the study, it enables students to academician writing skill, share their thoughts and opinions and they think that blog flourishes learning environment and they will use in their professional life.

In the study of Köskeroglu Büyükimdat et al. (2011) which is carried out with 338 students who study in BOTE and in three different universities, they researched students' perspective about Facebook usage conditions and determination conditions as career developments tools. 
At the end of the study which the hybrid method is used in, it seen that BOTE instructors regard share, communication and socialization extents as significant in being used Facebook as career developments tools.

The purpose of this study is to evaluate faculty of education first-grade students' usage condition of Web 2.0 technologies.

This study is important because which level web $\mathbf{2 . 0}$ applications are used by faculty of education students' will be determined with this study.

For this purpose the answers of the following questions are sought in the research:

$>$ What is generally faculty of education students' the usage condition of Web 2.0 tools?

$>$ Faculty of education students' the usage condition of web 2.0 tools differentiates in terms of gender?

$>$ Faculty of education students' the usage condition of web 2.0 tools differentiates in terms of department?

$>$ Faculty of education students' the usage condition of web 2.0 tools differentiates in terms of high school type?

$>$ Faculty of education students' the usage condition of web $\mathbf{2 . 0}$ tools differentiates in terms of year of computer use?

$>$ Faculty of education students' the usage condition of web 2.0 tools differentiates in terms of year of Internet use?

$>$ Faculty of education students' the usage condition of web 2.0 tools differentiates in terms of year of weekly duration of computer usage?

$>$ Faculty of education students' the usage condition of web 2.0 tools differentiates in terms of year of weekly duration of Internet usage?

\section{METHOD}

\section{Research Model}

Since the study is descriptive of existing situation, is has determination quality as a situation suitable to survey model.

Population and Sample

Population of the study consists of 359 first-grade students who study in Faculty of Education, Istanbul University in 2008- 2009 academic year. Students who study in eight different departments are taken with accidental sampling in the study.

The information about departments of faculty of education students who attended to the study is seen in Table: 2.

It is seen that the numbers of students who attended to the study from different departments are close to each other.

Gender range of students who attended to the study is seen in Table 3 and 41 per cent of working group consists of boys while $\mathbf{5 7 . 9}$ per cent of working group consists of girls. The balance in terms of gender is considered. 
Table: 2

Distribution of Departments

\begin{tabular}{|c|c|c|c|c|c|c|c|c|c|}
\hline & 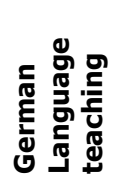 & 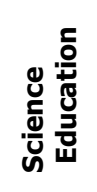 & 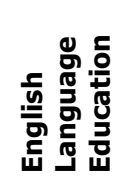 & 吾 & 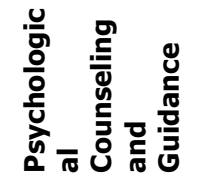 & 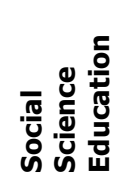 & 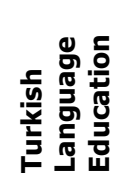 & 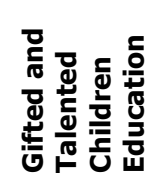 & Total \\
\hline $\mathbf{F}$ & 50 & 37 & 42 & 43 & 45 & 63 & 47 & 32 & 359 \\
\hline$\%$ & 13,9 & 10,3 & 11,7 & 12 & 12,5 & 17,5 & 13,1 & 8,9 & 100 \\
\hline
\end{tabular}

Table: 3

Distribution of Gender

\begin{tabular}{cccc}
\hline & Male & Female & Total \\
\hline f & 151 & 208 & 359 \\
$\%$ & 42,1 & 57,9 & 100 \\
\hline
\end{tabular}

Data Collection Tool

Data collection tool which is used in the study is 18 items survey developed by researcher. Data collection tool consist of two sections. Personal knowledge related to those participating in survey is involved in the first section.

18 items aimed at students' usage conditions of web 2.0 applications are involved in the second section. While some items involved in the survey are multiple choices, more than one option can be marked when some questions are answered.

Opinions of three experts in computer and instructional technologies are received for comprehensibility, extent and face validity of statements involving in the survey. In the direction of opinions received, required arrangements are carried out.

\section{Data Analysis}

The survey is practiced over the Internet by being used QuestionPro Research Software and result data is collected with this software. Statistical analyses are made in SPSS package program. For stating whether or not a significant difference is in between averages for personal features in the analysis of data, t-test, one way analysis variance (ANOVA) is practiced.

\section{RESULTS AND DISCUSSION}

Findings and comments which are obtained at the end of analysis of data collected from teachers with the survey are involved in this part of the study.

In the study, demographic information such as faculty of education students' gender, department and high school which they graduate are handled. 
Table: 4

General Usage Conditions of Web 2.0 Tools

\begin{tabular}{|c|c|c|c|c|c|c|}
\hline & \multicolumn{2}{|c|}{ Yes } & \multicolumn{2}{|c|}{ No } & \multicolumn{2}{|c|}{ No Idea } \\
\hline & $\mathbf{f}$ & $\%$ & $\mathbf{f}$ & $\%$ & $\mathbf{f}$ & $\%$ \\
\hline Following the publication of newspapers, magazines etc. & 297 & 80 & 54 & 20 & 8 & $\mathbf{0}$ \\
\hline Banking operation & 68 & 20 & 252 & 70 & 39 & 10 \\
\hline Downloading the song & 242 & 70 & 106 & 30 & 11 & $\mathbf{0}$ \\
\hline Listen to the song & 302 & 80 & 52 & 10 & 5 & $\mathbf{0}$ \\
\hline To share the song & 198 & 60 & 148 & 40 & 13 & $\mathbf{0}$ \\
\hline Downloading films, series, and so on & 151 & 40 & 190 & 50 & 18 & 10 \\
\hline Watching films, series, and so on & 275 & 80 & 72 & 20 & 12 & $\mathbf{0}$ \\
\hline To share films, series, and so on & 125 & 30 & 213 & 60 & 21 & 10 \\
\hline Using instant communication tools (MSN, Gtalk, Skype etc.) & 328 & 90 & 25 & 10 & 6 & $\mathbf{0}$ \\
\hline Following the photographs sharing sites Picasa Flickr etc. & 123 & 30 & 198 & 60 & 38 & 10 \\
\hline $\begin{array}{l}\text { Sharing photographs which taken themselves at } \\
\text { photo sharing sites (Picasa, Flickr, etc.). }\end{array}$ & 103 & 30 & 228 & 60 & 28 & 10 \\
\hline Following the video sharing sites YouTube Daily motion etc. & 258 & 70 & 90 & 30 & 11 & $\mathbf{0}$ \\
\hline $\begin{array}{l}\text { Following the video sharing sites taken by himself prepared to } \\
\text { share videos (YouTube, Daily Motion, etc.). }\end{array}$ & 76 & 20 & 265 & 70 & 18 & 10 \\
\hline $\begin{array}{l}\text { Having a profile on social networks (Facebook, MySpace, } \\
\text { Netlog, etc.) }\end{array}$ & 285 & 80 & 66 & 20 & 8 & $\mathbf{0}$ \\
\hline $\begin{array}{l}\text { Writing comments on social networks (Facebook, MySpace, } \\
\text { Netlog, etc.). }\end{array}$ & 272 & 80 & 79 & 20 & 8 & $\mathbf{0}$ \\
\hline Writing a blog (Blogger, Wordpress, blogger, etc). & 45 & $\mathbf{1 0}$ & 257 & 70 & 57 & 20 \\
\hline Reading blogs (Blogger, Wordpress, blogger, etc). & 101 & 30 & 201 & 60 & 57 & 20 \\
\hline Using collaboration tools (Google Docs, Zoho, ThinkFree, etc.). & 272 & 80 & 70 & 20 & 17 & $\mathbf{0}$ \\
\hline Using the wiki tools (Wiki, Squidoo, etc.) & 101 & 30 & 186 & 50 & 72 & 20 \\
\hline $\begin{array}{l}\text { Using social bookmarking sites (social bookmarks, del.icio.us, } \\
\text { digg) }\end{array}$ & 38 & 10 & 234 & 70 & 87 & 20 \\
\hline Using RSS subscription (Really Simple Syndication) & 21 & 10 & 220 & 60 & 118 & 30 \\
\hline $\begin{array}{l}\text { Play games over the Internet (Ogame, World of } \\
\text { Warcraft, Knight Online, etc.). }\end{array}$ & 148 & 40 & 193 & 50 & 18 & 10 \\
\hline $\begin{array}{l}\text { To do personal research (address discovery, } \\
\text { mapping information search, cinema, theater, cars, etc.) }\end{array}$ & 321 & 90 & 34 & 10 & 4 & $\mathbf{0}$ \\
\hline $\begin{array}{l}\text { To do research for educational purposes (homework, preparing } \\
\text { lessons, to prepare presentation, searching educational } \\
\text { content) }\end{array}$ & 333 & 90 & 19 & 10 & 7 & $\mathbf{0}$ \\
\hline Having an e-mail & 344 & 100 & 14 & $\mathbf{0}$ & 1 & $\mathbf{0}$ \\
\hline Using an e-mail & 340 & 90 & 18 & 10 & 1 & $\mathbf{0}$ \\
\hline
\end{tabular}

Faculty of education students' usage conditions of web $\mathbf{2 . 0}$ technologies are respectively examined whether they differentiate in terms of variances of gender, department, alma mater, place of Internet usage, year of Internet usage, average usage time of Internet, having technological tools. Faculty of education students' the usage condition of Web 2.0 tools is seen in Table: 4 . It is seen that almost all students $(\% 95)$ have e-mail address and use e-mail. Similarly, 93 per cent of students do education targeted researches and 90 per cent of them do personal researches. 
While 79 per cent of them have profiles in social networks, 76 per cent of them write comments in social networks. The other result which draws attention in this point is that range of students who download song is \%67; range of them who share song is \%55 while 84 per cent of them listen to song. The same condition is also true for film, series, watching video, downloading and sharing. Range of students who write blog is \%13 while range of students who read blog is \%28. It occurs that few students use banking transactions, social marking sites and RSS.

Table: 5

Usage Conditions of Web 2.0 Tools According to Departments

\begin{tabular}{|c|c|c|c|c|c|c|c|c|c|c|}
\hline & & & 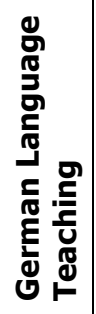 & 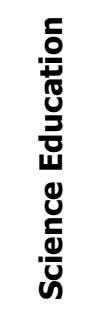 & 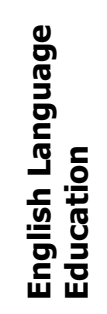 & 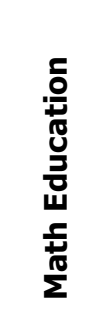 & 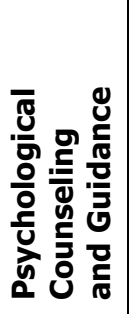 & 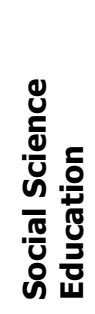 & 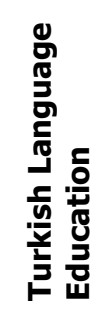 & 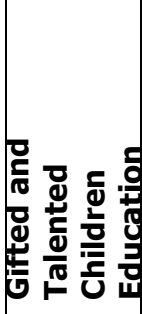 \\
\hline \multirow{6}{*}{$\begin{array}{l}\text { Using the } \\
\text { wiki tools } \\
\text { (Wiki, } \\
\text { Squidoo, } \\
\text { etc.) }\end{array}$} & \multirow{2}{*}{ Yes } & $f$ & 24 & 8 & 6 & 12 & 11 & 21 & 12 & 7 \\
\hline & & $\%$ & 48 & 21,6 & 14,3 & 27,9 & 24,4 & 33,3 & 25,5 & 21,9 \\
\hline & \multirow{2}{*}{ No } & $\mathbf{f}$ & 23 & 15 & 22 & 19 & 23 & 35 & 30 & 19 \\
\hline & & $\%$ & 46 & 40,5 & 52,4 & 44,2 & 51,1 & 55,6 & 63,8 & 59,4 \\
\hline & \multirow{2}{*}{$\begin{array}{c}\text { No } \\
\text { Idea }\end{array}$} & $f$ & 3 & 14 & 14 & 12 & 11 & 7 & 5 & 6 \\
\hline & & $\%$ & 6 & 37,8 & 33,3 & 27,9 & 24,4 & 11,1 & 10,6 & 18,8 \\
\hline \multirow{6}{*}{$\begin{array}{l}\text { Using social } \\
\text { bookmarking } \\
\text { sites (social } \\
\text { bookmarks, } \\
\text { del.icio.us, } \\
\text { digg) }\end{array}$} & \multirow{2}{*}{ Yes } & $f$ & 4 & 4 & 3 & 3 & 3 & 10 & 4 & 7 \\
\hline & & $\%$ & 8 & 10,8 & 7,1 & 7 & 6,7 & 15,9 & 8,5 & 21,9 \\
\hline & \multirow{2}{*}{ No } & f & 38 & 17 & 25 & 24 & 25 & 48 & 37 & 20 \\
\hline & & $\%$ & 76 & 45,9 & 59,5 & 55,8 & 55,6 & 76,2 & 78,7 & 62,5 \\
\hline & \multirow{2}{*}{$\begin{array}{c}\text { No } \\
\text { Idea }\end{array}$} & f & 8 & 16 & 14 & 16 & 17 & 5 & 6 & 5 \\
\hline & & $\%$ & 16 & 43,2 & 33,3 & 37,2 & 37,8 & 7,9 & 12,8 & 15,6 \\
\hline \multirow{6}{*}{$\begin{array}{l}\text { Using RSS } \\
\text { subscription } \\
\text { (Really } \\
\text { Simple } \\
\text { Syndication) }\end{array}$} & \multirow{2}{*}{ Yes } & $f$ & 2 & 2 & 0 & 1 & 3 & 6 & 3 & 4 \\
\hline & & $\%$ & 4 & 5,4 & 0 & 2,3 & 6,7 & 9,5 & 6,4 & 12,5 \\
\hline & \multirow{2}{*}{ No } & $f$ & 40 & 15 & 28 & 23 & 20 & 44 & 30 & 20 \\
\hline & & $\%$ & 80 & 40,5 & 66,7 & 53,5 & 44,4 & 69,8 & 63,8 & 62,5 \\
\hline & \multirow{2}{*}{$\begin{array}{c}\text { No } \\
\text { Idea }\end{array}$} & f & 8 & 20 & 14 & 19 & 22 & 13 & 14 & 8 \\
\hline & & $\%$ & 16 & 54,1 & 33,3 & 44,2 & 48,9 & 20,6 & 29,8 & 25 \\
\hline
\end{tabular}

Whether or not there is significant difference between faculties of education students' the usages of Web 2.0 tools in terms of their departments was researched and the findings are seen in Table: 5. The usage of wiki tools, social marking sites and RSS subscription only show significant difference in terms of departments $(p<0.05)$. While wiki tools are used at most by department of German Teaching students, they are used at least by department of English Teaching students. 
It is seen that range of wiki usage of other departments is close to each other. When the usage of social marking sites and RSS is considered, it is seen that while students of teaching of gifted have the highest usage range, students who use at least are respectively Psychological Counseling and Guidance students with \%6.7 and English Teaching students with \%0.

Table: 6

Usage Conditions of Web 2.0 Tools According to Gender

\begin{tabular}{|c|c|c|c|c|}
\hline & & & Male & Female \\
\hline \multirow{6}{*}{ Listen to the song } & \multirow{2}{*}{ Yes } & $\mathbf{f}$ & 118 & 184 \\
\hline & & $\%$ & 78,1 & 88,5 \\
\hline & \multirow{2}{*}{ No } & $\mathbf{f}$ & 29 & 23 \\
\hline & & $\%$ & 19,2 & 11,1 \\
\hline & \multirow{2}{*}{ No Idea } & f & 4 & 1 \\
\hline & & $\%$ & 2,6 & 0,5 \\
\hline \multirow{6}{*}{ Downloading films, series, and so on } & \multirow{2}{*}{ Yes } & $\mathbf{f}$ & 74 & 77 \\
\hline & & $\%$ & 49 & 37 \\
\hline & \multirow{2}{*}{ No } & $\mathbf{f}$ & 66 & 124 \\
\hline & & $\%$ & 43,7 & 59,6 \\
\hline & \multirow{2}{*}{ No Idea } & $\mathbf{f}$ & 11 & 7 \\
\hline & & $\%$ & 7,3 & 3,4 \\
\hline \multirow{6}{*}{ Watching films, series, and so on } & \multirow{2}{*}{ Yes } & $\mathbf{f}$ & 110 & 165 \\
\hline & & $\%$ & 72,8 & 79,3 \\
\hline & \multirow{2}{*}{ No } & $\mathbf{f}$ & 34 & 38 \\
\hline & & $\%$ & 22,5 & 18,3 \\
\hline & \multirow{2}{*}{ No Idea } & $\mathbf{f}$ & 7 & 5 \\
\hline & & $\%$ & 4,6 & 2,4 \\
\hline \multirow{6}{*}{$\begin{array}{l}\text { Following the video sharing sites } \\
\text { Youtube Daily motion etc. }\end{array}$} & \multirow{2}{*}{ Yes } & $\mathbf{f}$ & 116 & 142 \\
\hline & & $\%$ & 76,8 & 68,3 \\
\hline & \multirow{2}{*}{ No } & $\mathbf{f}$ & 32 & 58 \\
\hline & & $\%$ & 21,2 & 27,9 \\
\hline & \multirow{2}{*}{ No Idea } & $\mathbf{f}$ & 3 & 8 \\
\hline & & $\%$ & 2 & 3,8 \\
\hline
\end{tabular}

Whether or not there is significant difference between faculties of education students' the usages of Web 2.0 tools in terms of their genders was researched and the findings are seen in Table 6, Table 7, and Table: 8. Usage of many Web 2.0 tools shows significant difference in terms of genders $(p<0.05)$. While tools which consist of actions such as listening, downloading, watching are presented in Table 7, shares are presented in Table 8; other tools are presented in Table: 9. While ranges of girls students are higher in listening song and watching film, series and etc., range of boys are higher in downloading film, series and etc. and following video sharing sites. 
Table: 7 Usage Conditions of Web 2.0 Tools According to Gender

\begin{tabular}{|c|c|c|c|c|}
\hline & & & Male & Female \\
\hline \multirow{6}{*}{ To share films, series, and so on } & \multirow{2}{*}{ Yes } & $f$ & 61 & 64 \\
\hline & & $\%$ & 40,4 & 30,8 \\
\hline & \multirow{2}{*}{ No } & $\mathbf{f}$ & 77 & 136 \\
\hline & & $\%$ & 51 & 65,4 \\
\hline & \multirow{2}{*}{ No Idea } & $f$ & 13 & 8 \\
\hline & & $\%$ & 8,6 & 3,8 \\
\hline \multirow{6}{*}{$\begin{array}{l}\text { Sharing photographs which taken } \\
\text { themselves at photo sharing sites (Picasa, } \\
\text { Flickr, etc.). }\end{array}$} & \multirow{2}{*}{ Yes } & f & 56 & 47 \\
\hline & & $\%$ & 37,1 & 22,6 \\
\hline & \multirow{2}{*}{ No } & $\mathbf{f}$ & 82 & 146 \\
\hline & & $\%$ & 54,3 & 70,2 \\
\hline & \multirow{2}{*}{ No Idea } & $f$ & 13 & 15 \\
\hline & & $\%$ & 8,6 & 7,2 \\
\hline \multirow{6}{*}{$\begin{array}{l}\text { Sharing videos which taken and prepared } \\
\text { themselves at sharing sites (Youtube, } \\
\text { Daily motion, etc.). }\end{array}$} & \multirow{2}{*}{ Yes } & f & 51 & 25 \\
\hline & & $\%$ & 33,8 & 12 \\
\hline & \multirow{2}{*}{ No } & $\mathbf{f}$ & 91 & 174 \\
\hline & & $\%$ & 60,3 & 83,7 \\
\hline & \multirow[b]{2}{*}{ No Idea } & f & 9 & 9 \\
\hline & & $\%$ & 6 & 4,3 \\
\hline
\end{tabular}

Range of boys is higher than girls in all sharing ranges.

Table: 8 Usage Conditions of Web 2.0 Tools According to Gender

\begin{tabular}{|c|c|c|c|c|}
\hline & & & Male & Female \\
\hline \multirow{6}{*}{$\begin{array}{l}\text { Using collaboration tools (Google } \\
\text { Docs, Zoho, ThinkFree, etc.). }\end{array}$} & \multirow{2}{*}{ Yes } & $f$ & 102 & 170 \\
\hline & & $\%$ & 67,5 & 81,7 \\
\hline & \multirow{2}{*}{ No } & f & 41 & 29 \\
\hline & & $\%$ & 27,2 & 13,9 \\
\hline & \multirow{2}{*}{ No Idea } & f & 8 & 9 \\
\hline & & $\%$ & 5,3 & 4,3 \\
\hline \multirow{6}{*}{$\begin{array}{l}\text { Using social bookmarking sites (social } \\
\text { bookmarks, del.icio.us, digg) }\end{array}$} & \multirow{2}{*}{ Yes } & f & 18 & 20 \\
\hline & & $\%$ & 11,9 & 9,6 \\
\hline & \multirow[b]{2}{*}{ No } & f & 106 & 128 \\
\hline & & $\%$ & 70,2 & 61,5 \\
\hline & \multirow{2}{*}{ No Idea } & f & 27 & 60 \\
\hline & & $\%$ & 17,9 & 28,8 \\
\hline \multirow{6}{*}{$\begin{array}{l}\text { To do Personal Research (address } \\
\text { discovery, mapping information } \\
\text { search, cinema, theater, cars, etc.) }\end{array}$} & \multirow{2}{*}{ Yes } & f & 129 & 192 \\
\hline & & $\%$ & 85,4 & 92,3 \\
\hline & \multirow{2}{*}{ No } & $f$ & 19 & 15 \\
\hline & & $\%$ & 12,6 & 7,2 \\
\hline & \multirow{2}{*}{ No Idea } & $f$ & 3 & 1 \\
\hline & & $\%$ & 2 & 0,5 \\
\hline \multirow{6}{*}{$\begin{array}{l}\text { To do research for educational } \\
\text { purposes (homework, preparing } \\
\text { lessons, to prepare presentation, } \\
\text { searching educational content) }\end{array}$} & \multirow{2}{*}{ Yes } & $f$ & 133 & 200 \\
\hline & & $\%$ & 88,1 & 96,2 \\
\hline & \multirow{2}{*}{ No } & f & 13 & 6 \\
\hline & & $\%$ & 8,6 & 2,9 \\
\hline & \multirow{2}{*}{ No Idea } & f & 5 & 2 \\
\hline & & $\%$ & 3,3 & 1 \\
\hline \multirow{6}{*}{ Having an e-mail } & \multirow{2}{*}{ Yes } & $\mathbf{f}$ & 142 & 202 \\
\hline & & $\%$ & 94 & 97,1 \\
\hline & \multirow{2}{*}{ No } & f & 8 & 6 \\
\hline & & $\%$ & 5,3 & 2,9 \\
\hline & \multirow{2}{*}{ No Idea } & f & 1 & 0 \\
\hline & & $\%$ & 0,7 & 0 \\
\hline
\end{tabular}


Range of boys is higher in only usage of social marking sites and range of girls is higher in other Web 2.0 tools.

Table: 9

Usage Conditions of Web 2.0 Tools According to High School Types

\begin{tabular}{|c|c|c|c|c|c|c|c|}
\hline & & & 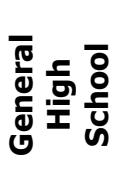 & 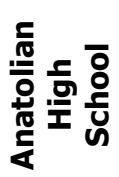 & 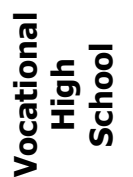 & 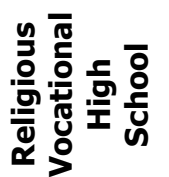 & 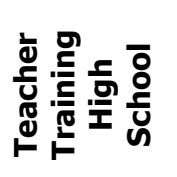 \\
\hline \multirow{6}{*}{$\begin{array}{l}\text { Sharing photographs } \\
\text { which taken themselves } \\
\text { at photo } \\
\text { sharing sites } \\
\text { (Picasa, Flickr, etc.). }\end{array}$} & \multirow{2}{*}{ Yes } & f & 29 & 24 & 6 & 0 & 44 \\
\hline & & $\%$ & 32,2 & 27 & 75 & $\mathbf{0}$ & 26,2 \\
\hline & \multirow{2}{*}{ No } & f & 52 & 62 & 2 & 4 & 108 \\
\hline & & $\%$ & 57,8 & 69,7 & 25 & 100 & 64,3 \\
\hline & \multirow{2}{*}{$\begin{array}{l}\text { No } \\
\text { Idea }\end{array}$} & $f$ & 9 & 3 & 0 & 0 & 16 \\
\hline & & $\%$ & 10 & 3,4 & $\mathbf{0}$ & 0 & 9,5 \\
\hline \multirow{6}{*}{$\begin{array}{l}\text { Following the video } \\
\text { sharingsites taken by } \\
\text { himself prepared to } \\
\text { share videos (YouTube, } \\
\text { Daily } \\
\text { Motion, etc.). }\end{array}$} & \multirow{2}{*}{ Yes } & $\mathbf{f}$ & 19 & 20 & 3 & $\mathbf{0}$ & 34 \\
\hline & & $\%$ & 21,1 & 22,5 & 37,5 & 0 & 20,2 \\
\hline & \multirow[b]{2}{*}{ No } & $\mathbf{f}$ & 65 & 66 & 5 & 4 & 125 \\
\hline & & $\%$ & 72,2 & 74,2 & 62,5 & 100 & 74,4 \\
\hline & \multirow{2}{*}{\begin{tabular}{|l|} 
No \\
Idea \\
\end{tabular}} & f & 6 & 3 & $\mathbf{0}$ & 0 & 9 \\
\hline & & $\%$ & 6,7 & 3,4 & 0 & 0 & 5,4 \\
\hline \multirow{6}{*}{$\begin{array}{l}\text { Using the wiki tools } \\
\text { (Wiki, Squidoo, etc.). }\end{array}$} & \multirow{2}{*}{ Yes } & $\mathbf{f}$ & 35 & 24 & 6 & 1 & 35 \\
\hline & & $\%$ & 38,9 & 27 & 75 & 25 & 20,8 \\
\hline & \multirow{2}{*}{ No } & $f$ & 40 & 54 & 2 & 2 & 88 \\
\hline & & $\%$ & 44,4 & 60,7 & 25 & 50 & 52,4 \\
\hline & \multirow{2}{*}{$\begin{array}{l}\text { No } \\
\text { Idea }\end{array}$} & $\mathbf{f}$ & 15 & 11 & $\mathbf{0}$ & 1 & 45 \\
\hline & & $\%$ & 16,7 & 12,4 & $\mathbf{0}$ & 25 & 26,8 \\
\hline \multirow{6}{*}{ Having an e-mail } & \multirow{2}{*}{ Yes } & f & 81 & 87 & 8 & 3 & 165 \\
\hline & & $\%$ & 90 & 97,8 & 100 & 75 & 98,2 \\
\hline & \multirow[b]{2}{*}{ No } & $\mathbf{f}$ & 8 & 2 & 0 & 1 & 3 \\
\hline & & $\%$ & 8,9 & 2,2 & $\mathbf{0}$ & 25 & 1,8 \\
\hline & \multirow{2}{*}{$\begin{array}{l}\text { No } \\
\text { Idea }\end{array}$} & f & 1 & 0 & 0 & 0 & 0 \\
\hline & & $\%$ & 1,1 & 0 & 0 & 0 & 0 \\
\hline
\end{tabular}

Whether or not there is significant difference between faculties of education students' the usages of Web 2.0 tools in terms of their high school which they graduate was researched and the findings are seen in Table 9. Sharing only photographs, which they take, in photograph sharing sites and sharing videos, which they shoot, in video sharing sites, usage of wiki tools and having e-mail account show significant difference in terms of departments $(p<0.05)$. When usage ranges of four Web 2.0 tools which are indicated in Table 9, it seen that while students having the most usage range are bachelors of Vocational High School, students having the least usage range are bachelors of Religious Vocational High School. It is seen that ranges of other schools are close to each other. 
Table: 10

Usage Conditions of Web 2.0 Tools According to Year of Computer Use

\begin{tabular}{|c|c|c|c|c|c|c|c|c|c|c|c|c|}
\hline & & & 1 & 2 & 3 & 4 & 5 & 6 & 7 & 8 & 9 & 10 \\
\hline \multirow{6}{*}{ To share song } & \multirow{2}{*}{ Yes } & $f$ & 4 & 11 & 9 & 20 & 23 & 27 & 20 & 26 & 15 & 43 \\
\hline & & $\%$ & 26,7 & 44 & 45 & 47,6 & 46,9 & 55,1 & 66,7 & 63,4 & 65,2 & 66,2 \\
\hline & \multirow{2}{*}{ No } & $\mathbf{f}$ & 7 & 11 & 11 & 21 & 25 & 22 & 8 & 14 & 8 & 21 \\
\hline & & $\%$ & 46,7 & 44 & 55 & 50 & 51 & 44,9 & 26,7 & 34,1 & 34,8 & 32,3 \\
\hline & \multirow{2}{*}{$\begin{array}{l}\text { No } \\
\text { Idea }\end{array}$} & $\mathbf{f}$ & 4 & 3 & $\mathbf{0}$ & 1 & 1 & 0 & 2 & 1 & $\mathbf{0}$ & 1 \\
\hline & & $\%$ & 26,7 & 12 & $\mathbf{0}$ & 2,4 & 2 & $\mathbf{0}$ & 6,7 & 2,4 & $\mathbf{0}$ & 1,5 \\
\hline \multirow{6}{*}{$\begin{array}{l}\text { Downloading } \\
\text { films, series, } \\
\text { and so on }\end{array}$} & \multirow{2}{*}{ Yes } & $\mathbf{f}$ & 2 & 8 & 8 & 12 & 23 & 19 & 16 & 21 & 9 & 33 \\
\hline & & $\%$ & 13,3 & 32 & 40 & 28,6 & 46,9 & 38,8 & 53,3 & 51,2 & 39,1 & 50,8 \\
\hline & \multirow{2}{*}{ No } & $\mathbf{f}$ & 8 & 13 & 12 & 28 & 24 & 29 & 11 & 20 & 14 & 31 \\
\hline & & $\%$ & 53,3 & 52 & 60 & 66,7 & 49 & 59,2 & 36,7 & 48,8 & 60,9 & 47,7 \\
\hline & \multirow{2}{*}{$\begin{array}{l}\text { No } \\
\text { Idea }\end{array}$} & $\mathbf{f}$ & 5 & 4 & 0 & 2 & 2 & 1 & 3 & 0 & 0 & 1 \\
\hline & & $\%$ & 33,3 & 16 & 0 & 4,8 & 4,1 & 2 & 10 & 0 & 0 & 1,5 \\
\hline \multirow{6}{*}{$\begin{array}{l}\text { To share } \\
\text { films, series, } \\
\text { and so on }\end{array}$} & \multirow{2}{*}{ Yes } & $\mathbf{f}$ & 1 & 5 & 7 & 15 & 15 & 11 & 14 & 18 & 8 & 31 \\
\hline & & $\%$ & 6,7 & 20 & 35 & 35,7 & 30,6 & 22,4 & 46,7 & 43,9 & 34,8 & 47,7 \\
\hline & \multirow{2}{*}{ No } & f & 10 & 15 & 12 & 25 & 33 & 36 & 14 & 21 & 13 & 34 \\
\hline & & $\%$ & 66,7 & 60 & 60 & 59,5 & 67,3 & 73,5 & 46,7 & 51,2 & 56,5 & 52,3 \\
\hline & \multirow{2}{*}{$\begin{array}{l}\text { No } \\
\text { Idea }\end{array}$} & f & 4 & 5 & 1 & 2 & 1 & 2 & 2 & 2 & 2 & 0 \\
\hline & & $\%$ & 26,7 & 20 & 5 & 4,8 & 2 & 4,1 & 6,7 & 4,9 & 8,7 & 0 \\
\hline \multirow{6}{*}{$\begin{array}{l}\text { Following the } \\
\text { video sharing } \\
\text { sites taken by } \\
\text { himself } \\
\text { prepared to } \\
\text { share videos } \\
\text { (YouTube, } \\
\text { Daily Motion, } \\
\text { etc.). }\end{array}$} & \multirow{3}{*}{ Yes } & f & 6 & 14 & 15 & 31 & 36 & 36 & 19 & 34 & 16 & 51 \\
\hline & & $\%$ & 40 & 56 & 75 & 73,8 & 73,5 & 73,5 & 63,3 & 82,9 & 69,6 & 78,5 \\
\hline & & $\mathbf{f}$ & 4 & 9 & 4 & 11 & 13 & 13 & 10 & 6 & 7 & 13 \\
\hline & No & $\%$ & 26,7 & 36 & 20 & 26,2 & 26,5 & 26,5 & 33,3 & 14,6 & 30,4 & 20 \\
\hline & \multirow[t]{2}{*}{$\begin{array}{c}\text { No } \\
\text { Idea }\end{array}$} & $\mathbf{f}$ & 5 & 2 & 1 & 0 & 0 & 0 & 1 & 1 & 0 & 1 \\
\hline & & $\%$ & 33,3 & 8 & 5 & 0 & 0 & 0 & 3,3 & 2,4 & 0 & 1,5 \\
\hline
\end{tabular}

Whether or not there is significant difference between faculties of education students' the usages of Web 2.0 tools in terms of their year of computer usage was researched and the findings related to film, video and music are presented in Table 10; other findings are presented in Table: 11.

Usage of many Web 2.0 tools shows significant difference in terms of the year of computer usage $(p<0.05)$. When Table 10 is examined, it is seen that usage range of Web 2.0 tools increases as the year of computer usage increases in almost all tools. 


\begin{tabular}{|c|c|c|c|c|c|c|c|c|c|c|c|c|}
\hline & & & 1 & 2 & 3 & 4 & 5 & 6 & 7 & 8 & 9 & 10 \\
\hline \multirow{6}{*}{$\begin{array}{l}\text { Having a profile on } \\
\text { social networks } \\
\text { (facebook, myspace, } \\
\text { netlog, etc.). }\end{array}$} & \multirow{2}{*}{ Yes } & $\mathbf{f}$ & 7 & 19 & 15 & 31 & 39 & 35 & 22 & 38 & 20 & 59 \\
\hline & & $\%$ & 46,7 & 76 & 75 & 73,8 & 79,6 & 71,4 & 73,3 & 92,7 & 87 & 90,8 \\
\hline & \multirow{2}{*}{ No } & $\mathbf{f}$ & 3 & 5 & 4 & 11 & 10 & 14 & 7 & 3 & 3 & 6 \\
\hline & & $\%$ & 20 & 20 & 20 & 26,2 & 20,4 & 28,6 & 23,3 & 7,3 & 13 & 9,2 \\
\hline & \multirow{2}{*}{$\begin{array}{c}\text { No } \\
\text { Idea }\end{array}$} & $\mathbf{f}$ & 5 & 1 & 1 & 0 & 0 & 0 & 1 & 0 & 0 & 0 \\
\hline & & $\%$ & 33,3 & 4 & 5 & 0 & 0 & 0 & 3,3 & 0 & 0 & 0 \\
\hline \multirow{6}{*}{$\begin{array}{l}\text { Writing comments } \\
\text { on social networks } \\
\text { (facebook, myspace, } \\
\text { netlog, etc.). }\end{array}$} & \multirow{2}{*}{ Yes } & $\mathbf{f}$ & 7 & 17 & 12 & 31 & 38 & 34 & 22 & 36 & 18 & 57 \\
\hline & & $\%$ & 46,7 & 68 & 60 & 73,8 & 77,6 & 69,4 & 73,3 & 87,8 & 78,3 & 87,7 \\
\hline & \multirow{2}{*}{ No } & $\mathbf{f}$ & 3 & 7 & 7 & 10 & 11 & 15 & 8 & 5 & 5 & 8 \\
\hline & & $\%$ & 20 & 28 & 35 & 23,8 & 22,4 & 30,6 & 26,7 & 12,2 & 21,7 & 12,3 \\
\hline & \multirow{2}{*}{$\begin{array}{c}\text { No } \\
\text { Idea }\end{array}$} & $\mathbf{f}$ & 5 & 1 & 1 & 1 & 0 & 0 & 0 & 0 & 0 & 0 \\
\hline & & $\%$ & 33,3 & 4 & 5 & 2,4 & 0 & 0 & 0 & 0 & 0 & 0 \\
\hline \multirow{6}{*}{$\begin{array}{l}\text { Writing a blog } \\
\text { (Blogger, Wordpress, } \\
\text { blogger, etc). }\end{array}$} & \multirow{2}{*}{ Yes } & $\mathbf{f}$ & 0 & 3 & 1 & 7 & 4 & 5 & 7 & 3 & 1 & 14 \\
\hline & & $\%$ & 0 & 12 & 5 & 16,7 & 8,2 & 10,2 & 23,3 & 7,3 & 4,3 & 21,5 \\
\hline & \multirow{2}{*}{ No } & $\mathbf{f}$ & 8 & 14 & 16 & 28 & 38 & 40 & 19 & 31 & 17 & 46 \\
\hline & & $\%$ & 53,3 & 56 & 80 & 66,7 & 77,6 & 81,6 & 63,3 & 75,6 & 73,9 & 70,8 \\
\hline & \multirow{2}{*}{$\begin{array}{c}\text { No } \\
\text { Idea }\end{array}$} & $\mathbf{f}$ & 7 & 8 & 3 & 7 & 7 & 4 & 4 & 7 & 5 & 5 \\
\hline & & $\%$ & 46,7 & 32 & 15 & 16,7 & 14,3 & 8,2 & 13,3 & 17,1 & 21,7 & 7,7 \\
\hline \multirow{6}{*}{$\begin{array}{l}\text { Reading blogs } \\
\text { (Blogger, Wordpress, } \\
\text { blogger, etc). }\end{array}$} & \multirow{2}{*}{ Yes } & $\mathbf{f}$ & 1 & 5 & 3 & 9 & 11 & 17 & 14 & 9 & 5 & 27 \\
\hline & & $\%$ & 6,7 & 20 & 15 & 21,4 & 22,4 & 34,7 & 46,7 & 22 & 21,7 & 41,5 \\
\hline & \multirow{2}{*}{ No } & $\mathbf{f}$ & 7 & 12 & 13 & 26 & 31 & 28 & 13 & 25 & 13 & 33 \\
\hline & & $\%$ & 46,7 & 48 & 65 & 61,9 & 63,3 & 57,1 & 43,3 & 61 & 56,5 & 50,8 \\
\hline & \multirow{2}{*}{$\begin{array}{c}\text { No } \\
\text { Idea }\end{array}$} & $\mathbf{f}$ & 7 & 8 & 4 & 7 & 7 & 4 & 3 & 7 & 5 & 5 \\
\hline & & $\%$ & 46,7 & 32 & 20 & 16,7 & 14,3 & 8,2 & 10 & 17,1 & 21,7 & 7,7 \\
\hline
\end{tabular}

When Table: 11 is examined, the similar condition is seen; the same condition is not seen in blog writing. It is seen that range of blog writing does not increase as the year of computer usage increases. 
Table 12

Usage Conditions of Web 2.0 Tools According to Year of Internet use

\begin{tabular}{|c|c|c|c|c|c|c|c|c|c|c|c|c|}
\hline & & & 1 & 2 & 3 & 4 & 5 & 6 & 7 & 8 & 9 & 10 \\
\hline \multirow{6}{*}{$\begin{array}{l}\text { Downloading } \\
\text { song }\end{array}$} & \multirow{2}{*}{ Yes } & $f$ & 4 & 26 & 18 & 52 & 51 & 27 & 20 & 24 & 5 & 15 \\
\hline & & $\%$ & 25 & 66,7 & 51,4 & 71,2 & 69,9 & 69,2 & 83,3 & 75 & 55,6 & 78,9 \\
\hline & \multirow{2}{*}{ No } & f & 8 & 12 & 16 & 19 & 21 & 12 & 3 & 8 & 4 & 3 \\
\hline & & $\%$ & 50 & 30,8 & 45,7 & 26 & 28,8 & 30,8 & 12,5 & 25 & 44,4 & 15,8 \\
\hline & \multirow{2}{*}{$\begin{array}{l}\text { No } \\
\text { Idea }\end{array}$} & $f$ & 4 & 1 & 1 & 2 & 1 & 0 & 1 & 0 & 0 & 1 \\
\hline & & $\%$ & 25 & 2,6 & 2,9 & 2,7 & 1,4 & 0 & 4,2 & 0 & 0 & 5,3 \\
\hline \multirow{6}{*}{$\begin{array}{l}\text { Downloading } \\
\text { films, series, } \\
\text { and so on }\end{array}$} & \multirow{2}{*}{ Yes } & f & 3 & 14 & 9 & 23 & 34 & 21 & 14 & 18 & 3 & 12 \\
\hline & & $\%$ & 18,8 & 35,9 & 25,7 & 31,5 & 46,6 & 53,8 & 58,3 & 56,3 & 33,3 & 63,2 \\
\hline & \multirow{2}{*}{ No } & f & 8 & 22 & 24 & 47 & 36 & 18 & 9 & 13 & 6 & 7 \\
\hline & & $\%$ & 50 & 56,4 & 68,6 & 64,4 & 49,3 & 46,2 & 37,5 & 40,6 & 66,7 & 36,8 \\
\hline & \multirow{2}{*}{$\begin{array}{l}\text { No } \\
\text { Idea }\end{array}$} & $f$ & 5 & 3 & 2 & 3 & 3 & 0 & 1 & 1 & 0 & 0 \\
\hline & & $\%$ & 31,3 & 7,7 & 5,7 & 4,1 & 4,1 & 0 & 4,2 & 3,1 & 0 & 0 \\
\hline \multirow{6}{*}{$\begin{array}{l}\text { Writing a blog } \\
\text { (Blogger, } \\
\text { Wordpress, } \\
\text { blogger, etc). }\end{array}$} & \multirow{2}{*}{ Yes } & f & 2 & 1 & 1 & 12 & 5 & 9 & 3 & 6 & 1 & 5 \\
\hline & & $\%$ & 12,5 & 2,6 & 2,9 & 16,4 & 6,8 & 23,1 & 12,5 & 18,8 & 11,1 & 26,3 \\
\hline & \multirow{2}{*}{ No } & f & 5 & 28 & 26 & 50 & 61 & 25 & 19 & 23 & 7 & 13 \\
\hline & & $\%$ & 31,3 & 71,8 & 74,3 & 68,5 & 83,6 & 64,1 & 79,2 & 71,9 & 77,8 & 68,4 \\
\hline & \multirow{2}{*}{$\begin{array}{c}\text { No } \\
\text { Idea }\end{array}$} & f & 9 & 10 & 8 & 11 & 7 & 5 & 2 & 3 & 1 & 1 \\
\hline & & $\%$ & 56,3 & 25,6 & 22,9 & 15,1 & 9,6 & 12,8 & 8,3 & 9,4 & 11,1 & 5,3 \\
\hline \multirow{6}{*}{$\begin{array}{l}\text { Reading blogs } \\
\text { (Blogger, } \\
\text { Wordpress, } \\
\text { blogger, etc). }\end{array}$} & \multirow{2}{*}{ Yes } & f & 2 & 6 & 4 & 24 & 16 & 16 & 7 & 13 & 4 & 9 \\
\hline & & $\%$ & 12,5 & 15,4 & 11,4 & 32,9 & 21,9 & 41 & 29,2 & 40,6 & 44,4 & 47,4 \\
\hline & \multirow{2}{*}{ No } & f & 5 & 22 & 22 & 39 & 50 & 18 & 16 & 16 & 4 & 9 \\
\hline & & $\%$ & 31,3 & 56,4 & 62,9 & 53,4 & 68,5 & 46,2 & 66,7 & 50 & 44,4 & 47,4 \\
\hline & \multirow{2}{*}{$\begin{array}{c}\text { No } \\
\text { Idea }\end{array}$} & f & 9 & 11 & 9 & 10 & 7 & 5 & 1 & 3 & 1 & 1 \\
\hline & & $\%$ & 56,3 & 28,2 & 25,7 & 13,7 & 9,6 & 12,8 & 4,2 & 9,4 & 11,1 & 5,3 \\
\hline
\end{tabular}

Whether or not there is significant difference between faculties of education students' the usages of Web 2.0 tools in terms of their year of Internet usage was researched and the findings are seen in Table 12. Only song downloading, film and etc. downloading, blog writing and reading parts show significant difference in terms of the year of Internet usage $(p<0.05)$. The usage condition of Web 2.0 tools other than blog writing increases in direct proportion to the year of Internet usage. Ranges of blog writing are again low and this kind of range isn't mentioned.Whether or not there is significant difference between faculties of education students' the usages of Web 2.0 tools in terms of weekly duration of computer usage was researched and the findings are seen in Table: 13. 
Table: 13

The Relationship with Usage of Web 2.0 Tools and Weekly Computer Usage Time

\begin{tabular}{|c|c|c|c|}
\hline & & & Weekly Computer Usage Time \\
\hline \multirow{3}{*}{ Banking operations } & Yes & Mean & 18 \\
\hline & No & Mean & 11 \\
\hline & No Idea & Mean & 6 \\
\hline \multirow{3}{*}{ Downloading song } & Yes & Mean & 14 \\
\hline & No & Mean & 7 \\
\hline & No Idea & Mean & 3 \\
\hline \multirow{3}{*}{ To share song } & Yes & Mean & 15 \\
\hline & No & Mean & 9 \\
\hline & No Idea & Mean & 10 \\
\hline \multirow{3}{*}{ Downloading films, series, and so on } & Yes & Mean & 15 \\
\hline & No & Mean & 10 \\
\hline & No Idea & Mean & 9 \\
\hline \multirow{3}{*}{$\begin{array}{l}\text { Sharing photographs which taken } \\
\text { themselves at photo sharing sites (Picasa, } \\
\text { Flickr, etc.). }\end{array}$} & Yes & Mean & 15 \\
\hline & No & Mean & 11 \\
\hline & No Idea & Mean & 5 \\
\hline \multirow{3}{*}{$\begin{array}{l}\text { Reading blogs (Blogger, Wordpress, blogger, } \\
\text { etc). }\end{array}$} & Yes & Mean & 15 \\
\hline & No & Mean & 12 \\
\hline & No Idea & Mean & 8 \\
\hline \multirow{3}{*}{$\begin{array}{l}\text { Play games over the Internet (Ogame, } \\
\text { World of Warcraft, Knight Online, etc.). }\end{array}$} & Yes & Mean & 15 \\
\hline & No & Mean & 10 \\
\hline & No Idea & Mean & 5 \\
\hline
\end{tabular}

Table 14

The Relationship with Usage of Web 2.0 Tools and Weekly Internet Usage Time

\begin{tabular}{|c|c|c|c|}
\hline & & & Weekly Internet Usage Time \\
\hline \multirow{3}{*}{ To share song } & Yes & Mean & 14 \\
\hline & No & Mean & 8 \\
\hline & No Idea & Mean & 7 \\
\hline \multirow{3}{*}{ To share films, series, and so on } & Yes & Mean & 15 \\
\hline & No & Mean & 9 \\
\hline & No Idea & Mean & 7 \\
\hline \multirow{3}{*}{$\begin{array}{l}\text { Sharing photographs which taken themselves } \\
\text { at photo sharing sites (Picasa, Flickr, etc.). }\end{array}$} & Yes & Mean & 14 \\
\hline & No & Mean & 10 \\
\hline & No Idea & Mean & 4 \\
\hline \multirow{3}{*}{$\begin{array}{l}\text { Sharing videos which taken and prepared } \\
\text { themselves at sharing sites (YouTube, Daily } \\
\text { motion, etc.). }\end{array}$} & Yes & Mean & 16 \\
\hline & No & Mean & 10 \\
\hline & No Idea & Mean & 5 \\
\hline
\end{tabular}

Usage of many Web 2.0 tools shows significant difference in terms of weekly duration of computer usage $(p<0.05)$. It occurs that students, who have high weekly duration of computer usage on timely basis, use more developed Web 2.0 tools. 
Table: 15

The Relationship with Usage of Web 2.0 Tools and Weekly Internet Usage Time

\begin{tabular}{lllc}
\hline & & & Weekly Internet Usage Time \\
\hline Downloading song & Yes & Mean & 13 \\
& No & Mean & 6 \\
& No Idea & Mean & 3 \\
\hline Downloading films, series, and so on & Yes & Mean & 15 \\
& No & Mean & 8 \\
\hline \multirow{2}{*}{ Following the photo sharing sites (Picasa, } & No Idea & Mean & 6 \\
Flickr, etc.). & No & Mean & 14 \\
\hline \multirow{2}{*}{$\begin{array}{l}\text { Writing a blog (Blogger, Wordpress, } \\
\text { blogger, etc). }\end{array}$} & No Idea & Mean & 10 \\
& Yes & Mean & 6 \\
\hline \multirow{2}{*}{$\begin{array}{ll}\text { Neading blogs (Blogger, Wordpress, } \\
\text { blogger, etc). }\end{array}$} & No Idea & Mean & 17 \\
& Yes & Mean & 11 \\
\hline Whether or not there is signiffcant & No Idea & Mean & 6 \\
\hline
\end{tabular}

Whether or not there is significant difference between faculties of education students' the usages of Web 2.0 tools in terms of weekly duration of Internet usage was researched and the findings related to the share are presented in Table 14 and the others are presented in Table 15. Usage of many Web 2.0 tools shows significant difference in terms of weekly duration of Internet usage $(p<0.05)$. It occurs that students, who have high weekly duration of Internet usage on timely basis, use more developed Web 2.0 tools. When the usage condition of Web 2.0 is considered according to Ata (2011) Internet usage time, it occurs that usage of Web $\mathbf{2 . 0}$ generally increases as the duration of Internet usage increases.

\section{CONCLUSIONS AND RECOMMENDATIONS}

The aim of the study is to be examined faculty of education students' the usage condition of Web 2.0 tools in terms of various variables. It is seen in analyses which were practiced in line with this aim that faculty of education students' the usage condition of Web 2.0 tools differentiates in terms of departments, gender, high school which they graduate, the year of Internet and computer usage, weekly average duration of Internet and computer usage. It is seen that faculty of education students use immediate communication tools, social networks and e-mails at most; few students use banking transactions, social marking sites and RSS. Besides, it is found that the ranges of song, video and etc. listening, watching of students are higher than the ranges of downloading and sharing. It is seen that almost all students have e-mail address and use immediate communication tools from the point of the communication tool of the era and they prefer Internet instead of libraries for doing homework and researches. Atav, Akkoyunlu and Sağlam (2006) found that pre-service teachers highly use e-mail and immediate communication tools. 
Activeness of students in social networks also draws attention. Similar result is seen in the study of Ucak and Cakmak (2010) that students use immediate communication tools at most and they use social networks such as Facebook as the second. It is seen that while students highly listen song and watch video, the ranges of downloading and sharing of this are lower. Likewise, the range of students reading blog is lower than students writing blog.

The reason of this is to be thought that students tend to only use instead of sharing, generating. Uçak and Çakmak(2010) present by finding similar result that while students use wiki and blog, the action they performed at most is to watch; the action they performed at least is to continually write. It is thought that the reason that significant difference, which is found oriented department variable, differentiate the usage of aforesaid tools in terms of departments is to be used tools such as wiki by students as assistant tools in their courses.

It is thought that the reason that boy students much more share than girl students in the significant difference which is found oriented gender variable is socialization wanting of boy students. Çavuş and Gökdaş(2006) found that boys much more use the Internet as "social" purpose than girls. Also, girls do researches and use cooperation tools in especially personal and educational topics and this supports Çavuş and Gökdaş(2006)'s finding that girl students much more use the Internet as informative purpose than boy students. The same statement can be used for Web 2.0 tools. It is thought that the reason that vocational high schools have the highest range in aforesaid Web 2.0 tools of significant difference which is found for the good of vocational high school oriented high schools which are graduated is to be begun modular training and be used effectively the Internet in vocational high school. It is thought that computer experiences of students and individuals- expect for blog writing- who use longer years the Internet in significant difference oriented the year of computer and Internet usage variables much more use different web tools by increasing their skills.

It occurs that students who have high weekly Internet and computer usage oriented weekly Internet and computer variable much more use developed Web 2.0 tools. When the usage condition of Web 2.0 is considered according to Ata (2011) Internet usage time, it occurs that usage of Web 2.0 generally increases as the duration of Internet usage increases. It can be generally said that faculty of education students don't use Web 2.0 applications in the expected level. They slightly use especially forming blog and wiki which are advanced applications and pre-service teachers will use their further professional life. It is very important that pre-service teachers should learn how to use these tools as well as they should receive education of computer literacy in the faculty of education which trains teachers.

The other suggestion is that these tools should be integrated with courses which preservice teachers receive in the prevocational training. So, pre-service teachers can be easily used and be attuned to new technologies and methods in their teaching years. This study deals with Istanbul University Faculty of Education students. Different samples can be chosen or sample can be enlarged in the further researches. The research can be done for students of different faculties. As comparison can be made between students of different faculties, analyses can be thoroughly made by being benefited from qualitative research method. 
Acknowledgement: This paper is presented in 2. International Conference On II. International Conference on Interdisciplinary Research in Education (ICOINE 2013), 30 January-1 February 2013, Girne-KKTC

BIODATA and CONTACT ADDRESSES of the AUTHOR

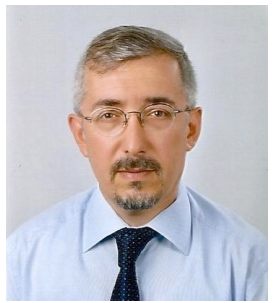

Assist. Prof. Dr. Ahmet AGIR currently employed as an Assistant Professor at Istanbul University, Hasan Ali Yücel Faculty of Education, Department of Computer Education and Instructional Technology. Also he is vice dean at Faculty of Open and Distance Education. He is specifically interested in distance education, knowledge management, and technology integration in education.

Ahmet AGIR

Hasan Ali Yücel Faculty of Education, Istanbul University, Istanbul, TURKEY

Email: ahmetagir@yahoo.com agir@istanbul.edu.tr

\section{REFERENCES}

Agir, A. (2010). Özel Öğretim Yöntemleri [Special Instructional Methods]. Ankara: Pegem A Publishing.

Alexander, B. (2006). A new way of innovation for teaching and learning. Educause Review, 41(2), 32-44.

Altun, A. (2008). Yapılandırmacı öğretim sürecinde viki kullanımı [Wiki Use in Constructivist Learning Process]. International Educational Technology Conference (IETC 2008), 152-155, Eskisehir, Turkey.

Anderson, P. (2007). What is Web 2.0? Ideas, technologies and implications for education. Joint Information Systems Committee (JISC). Retrieved on January 30, 2013 from http://www.jisc.ac.uk/media/documents/techwatch/tsw0701b.pdf

Ata, F. (2011). Üniversite Öğrencilerinin Web 2.0 Teknolojilerini Kullanım Durumları ile Bilgi Okuryazarlığı Öz-Yeterlik Algıları Arasındaki İlişkinin İncelenmesi [Examination of the Relationship Between Usage Conditions of Web 2.0 Technologies and Self-Efficacy Perception of University Students]. Unpublished master's thesis, Dokuz Eylül University, Izmir.

Atav, E., Akkoyunlu, B. \& Sağlam, N. (2006). Öğretmen adaylarının Internet'e erişim olanakları ve kullanım amaçları [Prospective Teachers' Internet Access Facilities and Their Internet Usage]. H.U. Journal of Education, 30, 37-44.

Baggetun, R. \& Wasson, B. (2006). Self-Regulated Learning and Open Writing. European Journal of Education, 41(3-4), 453-472.

Bartlett-Bragg, A. (2006). Reflections on pedagogy: Reframing practice to foster informal learning with social software. Retrieved on March 31, 2013 from http://matchsz.inf.elte.hu/TT/docs/Anne20Bartlett-Bragg.pdf 
Beldarrain, Y. (2006). Distance Education Trends. Distance Education, 27(2), 139-153.

Boulos, M. N. K., Maramba, I. \& Wheeler, S. (2006). Wikis, blogs and podcasts: A new generation of Web based tools for virtual collaborative clinical practice and education. BMC Medical Education, 6, 41-41.

Carminati, B., Ferrari, E. \& Perego, A. (2006). Rule-Based Access Control for Social Networks. OTM Workshops, 2, 1734-1744.

Chao, J. (2007). Student project collaboration using Wikis. Software Engineering Education and Training (CSEE\&T 2007), 255-261, Dublin, Ireland.

Churchill, D. (2009). Educational applications of Web 2.0: Using blogs to support teaching and learning. British Journal of Educational Technology, 40 (1), 179- 183.

Cych, L. (2006). Social Networks. In A. Pinder (Ed.), Emerging Technologies for Learning, (pp.32-41). Coventry: Becta ICT Research.

Cavus, H. \& Gökdas, I. (2006). Eğitim Fakültesi'nde öğrenim gören öğrencilerin Internet'ten yararlanma nedenleri ve kazanımları [The Benefiting Reasons From Internet And The Gains Of The Educational Faculty Students]. Yüzüncü Yıl University Journal of Faculty of Education, 3(3), 56-78.

Cuhadar, C. \& Kuzu, A. (2006). Öğretim ve Sosyal Etkileşim Amaçlı Blog Kullanımına Yönelik Öğrenci Görüşleri [Student Opinion For Education and Social Interaction Purpose Blog Usage]. International Educational Technology Conference (IETC 2006), 481-492, Famagusta, TRNC.

Dearstyne, B. W. (2007). Blogs, mashups, and wikis: Oh my!. The Information Management Journal, 41(4), 24-33.

Deperlioğlu, 0. \& Köse, U. (2010). Web 2.0 teknolojilerinin eğitim üzerindeki etkileri ve örnek bir öğrenme yaşantısı [Effects of Web 2.0 Technologies on the Education and An Example Learning Experience]. Akademik Bilişim 2010, Muğla, Turkey.

D'Souza, Q. (2006). Web 2.0 Ideals for Educators. Retrieved March 29, 2012 from http://www.teachinghacks.com/audio/100ideasWeb2educators.pdf

Dudeney, G., \& Hockly, N. (2007). How to Teach English With Technology. Essex: Pearson Longman.

Duffy, P. \& Bruns, A. (2006). The use of blogs, wikis and RSS in education: A conversation of possibilities. Online Learning and Teaching Conference 2006, 31-38, Brisbane, Australia.

Ebner, M. (2007). E-learning $2.0=$ e-learning $1.0+$ web 2.0?. The $2^{\text {nd }}$ International Conference on Availability, Reliability and Security, 1235-1239, Vienna, Austria. 
Efimova, L. (2004). Discovering the iceberg of knowledge work. In Proceedings of the Fifth European Conference on Organizational Knowledge, Learning, and Capabilities (OKLC 2004), Innsbruck, Austria.

Felix, L. \& Stolarz, D. (2006). Hands-On Guide to Video Blogging and Podcasting: Emerging Media Tools for Business Communication. Massachusetts: Focal Press.

Ferdig, R. E. \& Trammell, K.D. (2004). Content Delivery in the 'Blogosphere'. THE Journal, 31(7), 12-20.

Ferret, L. J. (2006). Wikis and e-learning. In P. Berman (Ed.), E-learning concepts and techniques (pp. 73-74). Bloomsburg, PA: Bloomsburg University.

Franklin, T. \& Van Harmelen, M. (2007). Web 2.0 for Content for Learning and Teaching in Higher Education. JISC Report. Retrieved on February 15, 2012 from

http://www.jisc.ac.uk/media/documents/programmes/digitalrepositories/Web2content -learning-and-teaching.pdf

Glogoff, S. (2003). Blogging In An Online Course: A Report on Student Satisfaction Among First-time Bloggers. World Conference on E-Learning in Corporate, Government, Healthcare, and Higher Education, 2160-2162, Phoenix, Arizona.

Godwin, P. (2007). The Web 2.0 challenge to information literacy. Paper presented at the 13th Conference on Professional Information Resources, Prague, Czech Republic.

Godwin-Jones, R. (2003). Emerging technologies-blogs and wikis: environments for on line collaboration. Language Learning \& Technology, $7(2), 12-16$.

Grassley, J.S., \& Bartoletti, R. (2009). Wikis and Blogs Tools for Online Interaction. Nurse Educator, 34(5), 209-213.

Grosseck, G. (2009). To use or not to use web 2.0 in higher education?. Procedia Social and Behavioral Sciences, 1, 478-482.

Gulsecen, S., Gürsul, F., Bayrakdar, B., Cilengir, S. \& Canım, S. (2010). Yeni Nesil Mobil Ogrenme Aracl: Podcast [New Generation Mobile Learning tool: Podcast].

Akademik Bilişim 2010, Mugla, Turkey.

Horzum, M. B. (2010). Öğretmenlerin Web 2.0 araçlarından haberdarlığı, kullanım sıklıkları ve amaçlarının çeşitli değişkenler açısından incelenmesi [Investigating teachers' Web 2.0 tools awareness, frequency and purposes of usage in terms of different variables]. International Journal of Human Sciences, $7(1), 603-634$.

Huffaker, D. (2005). The educated blogger: using weblogs to promote literacy in the classroom. AACE journal, 13(2), 91-98.

Isık, A. H., Ozkaraca, O. \& Güler, I. ( 2010). Mobil Öğrenme ve Podcast [Mobil Learning and Podcast]. Akademik Bilişim 2010, Mugla, Turkey. 
Johnson, A. (2004). Creating a writing course utilizing class and student blogs. The Internet TESL Journal, 10(8), Retrieved November 18, 2012 from

http://iteslj.org/Techniques/Johnson-Blogs

Kalelioglu, F. \& Gülbahar, Y. (2010). Investigating the usage of blogs in educational settings from multiple intelligences perspective The Turkish Online Journal of Educational Technology-. TOJET:, 9(2), 132-144.

Kaplan-Leiserson, E. (2005). Trend: Podcasting in academic and corporate learning. Learning Circuits. Retrieved on November 20, 2012 from

http://trainingthetrainers2010.pbworks.com/f/Podcasting+in+Academic+Learning.pdf

Kapp, K. M. \& O'Driscoll, T. (2010). Learning in 3D-Adding a New Dimension to Enterprise Learning and Collaboration. The USA: Pfeiffer A Willey Imprint.

Karaman, S., Yıldırım, S. \& Kaban, A. (2008). Öğrenme 2.0 yaygınlaşıyor: Web 2.0 Uygulamalarının Eğitimde kullanımına ilişkin araştırmalar ve sonuçları [Learning $\mathbf{2 . 0}$ is Spreading: Researches and Results about Use of Web 2.0 Applications in Education]. Inet tr'08 -Proceedings of XIII. Internet Conference in Turkey, 34-40, Ankara, Turkey.

Kayıslı, K., Hazar. H. \& Oztürk, U. (2011). The effect of social networks on student attitudes, III. International Congress of Educational Research, 1062-1071, Girne, TRNC.

Kentli, F., \& Polat, E. (2010). Podcasting Application Areas in Higher Education. The International Symposium on Open and Distance Learning (IODL), Eskisehir, Turkey.

Keskin, 0. N. (2010). Mobil Öğrenme Teknolojileri ve Araçları [Mobile Learning Technologies and Tools]. Akademik Bilişim 2010, Muğla, Turkey.

Kim, P., Hong, J., Bonk, C., \& Lim, G. (2009). Effects of group reflect variations in project based learning in a Web 2.0 learning space. Interactive Learning Environments, 19(4), 333-349-17.

Kolari, P., Finin, T. \& Joshi, A. (2006). SVMs for the Blogosphere: Blog Identification and Splog Detection. AAAI Spring Symposium on Computational Approaches to Analyzing Weblogs, Maryland, the USA.

Köskeroglu Büyükimdat, M, Albayrak, D., Uğur Erdoğmuş, F., Yıldırım, S., Eryol, G. \& Ataman, Y. E. (2011). Öğretmen adaylarının Facebook kullanımları ve Facebook'un mesleki gelişimlerindeki yeri konusundaki görüşleri [Pre-service Teachers' Facebook Usage And Their Perspectives About Facebook As A Professional Development Tool]. Ahi Evran University Journal of Faculty of Education, 12, 119-134.

Lenhart, A., \& Madden, M. (2007). Social networking websites and teens: An overview. Pew Internet and American Life Project report. Retrieved March 17, 2012 from http://www.pewInternet.org/PPF/r/198/report_display.asp

Li, L. \& Pitts, J. (2009). Does it really matter? Using virtual office hours to enhance student-faculty interaction. Journal of Information Systems Education, 20(2), 175185. 
Madden, M. \& Fox, S. (2006). Riding the waves of "Web 2.0": More than a buzzword, but still not easily defined. Pew Internet and American Life Project. Retrieved February 10,2012 from http://www.pewinternet.com/ /media/Files/Reports/2006/PIP_Web_2.0.pdf.pdf

Mansvelder-Longayroux, D.n D., Beijard, D., \& Verloop, N. (2007). The portfolio as a tool for stimulating reflection by student teachers. Teaching and Teacher Education, 23, 47-62.

McGarr, 0. (2009). A review of podcasting in higher education: Its influence on the traditional lecture. Australasian Journal of Educational Technology, 25(3), 309-321.

McLoughlin, C. \& Lee, M. J.W.(2007). Social software and participatory learning: Pedagogical choices with technology affordances in the Web 2.0 era. International Journal of Learning Technology, 3(1), 87-107.

Moon, J. A. (2006). Learning journals: A handbook for reflective practice and Professional development (2nd ed.). New York: Routledge.

Murugesan, S. (2007). Understanding Web 2.0. IEEE Computer Society, 9(4), 34-41.

O'Reilly, T. (2005). What is Web 2.0: design patterns and business models for the next generation of software. Retrieved July 8, 2012 from http://oreilly.com/web2/archive/what-is-web-20.html?page=1

Onat, F. \& Alikılıç O. A. (2009). Sosyal Ağ Sitelerinin Reklam ve Halkla ılişkiler Ortamları Olarak Değerlendirilmesi [Social Networking Sites Evaluation As Advertising And Public Relations Media Environment]. Journal of Yaşar University, 3(9), 1111-1143.

Patterson, L. (2006). The Technology Underlying Podcasts. IEEE Computer Society, 39(10), 103-105.

Perschbach, W. J. (2006). Blogging: an inquiry into the efficacy of a web-based technology for student reflection in community college computer science programs. Dissertation Abstracts International, (UMI No. 3206012).

Petter, C., Reich, K., \& Scheuermann, F. (2005). Analysis of Tools Supporting Communities

of Practice. Work \& Learn Together Project. Retrieved April 5, 2011 from

http://pdf.aminer.org/000/258/889/websites_wikis_weblogs_communities_of_practice and_knowledge.pdf

Richardson, W. (2006). Blogs, wikis, podcasts, and other powerful web tools for classrooms. Thousand Oaks, CA: Corwin Press.

Safran, C., Helic, D. \& Gütl, C. (2007). E-Learning practices and Web 2.0. The International Conference Interactive Computer Aided Learning (ICL2007), Villach, Austria.

Saunders, S. (2008). The Role of Social Networking Sites in Teacher Education Programs: A Qualitative Exploration. In K. McFerrin et al. (Eds.), Proceedings of Society for Information Technology \& Teacher Education International Conference 2008 (pp. 2223-2228). Chesapeake, VA: AACE. 
Schaffert, S., Bischof, D., Buerger, T., Gruber, A., Hilzensauer, W., \& Schaffert, S. (2006). Learning with semantic wikis. Proceedings of the First Workshop on Semantic Wikis From Wiki to Semantics (SemWiki2006), Budva, Montenegro.

Schwartz, L., Clark, S., Cossarin, M. \& Rudolph, J. (2004). Educational vikis: Features and selection criteria. International Review of Research in Open and Distance Learning, 5(1).

Ser, J. (2006). Be constructive: Blogs, podcasts, and wikis as constructivist learning tools. Learning Solutions, July, 2006.

Solomon, G., \& Schrum, L. (2007). Web 2.0: New tools, new schools. Washington, DC: International Society for Technology in Education.

Tekinarslan, E. (2008). Blogs: A qualitative investigation into an instructor and under graduate students' experiences. Australasian Journal of Educational Technology, 24(4),402-412.

Tekinarslan, E. \& Gürer, M.D. (2011). Abant Izzet Baysal Üniversitesi BOTE öğrencilerinin bilgi paylaşımı ve web yayın araçları olarak ağ günlükleri hakkındaki görüşleri [Opinios Of Abant Izzet Baysal University Ceit Students About Blogs As Information Sharing And Web Publishing Tools]. Kastamonu Journal of Education, 19 (3), 887-902.

Ucak Ozenc, N. \& Çakmak, T. (2010). Hacettepe Üniversitesi Bilgi ve Belge Yönetimi Öğrencilerinin Web 2.0 Araçlarını Kullanım Özellikleri [Using Web 2.0 ToolsCharacteristics Of Hacettepe University Information And Document Management Students']. 2. Uluslararası Değişen Dünyada Bilgi Yönetimi Sempozyumu, 44-53, Ankara, Turkey.

Usluel, Y. K., Mazman, S. G. \& Arıkan, A. (2009). Prospective teachers' awareness of collaborative web 2.0 tools. The IADIS International Conference WWW/ Internet 2009,Roma, Italy.

Usluel, Y. K. \& Mazman, S. G. (2009). Uzaktan Eğitim Uygulamaları. In B. Akkoyunlu (Ed.). Ogretmen ve Ogretmen Adayları için Bilgisayara Giriş [Introduction to Computer for Preservice Teachers and Teacher], pp.209-236, Istanbul: Kriter Yayınevi.

Wang, J. \& Fang, Y. (2005). Benefits of Cooperative Learning in Weblog Networks. (ERIC Document Reproduction Service No. ED490815).

Williams, J. B. \& Jacobs, J. (2004). Exploring the use of blogs as learning spaces in the higher education sector. Australasian Journal of Educational Technology, 20(2), 232-247.

Wu, W. S. (2006). The effect of blog peer review and teacher feedback on the revisions of EFL writers. Journal of Education and Foreign Languages and Literature, 3, 125-139.

Yang, S. H. (2009). Using blogs to enhance critical reflection and community of practice. Educational Technology \& Society, 12(2), 11-21.

Yuen, S. C. Y. \& Yuen, P. (2008). Social Networks in Education. In C. Bonk et al. (Eds.), Proceedings of World Conference on E-Learning in Corporate, Government, Healthcare, and Higher Education 2008 (pp. 1408-1412). Chesapeake, VA: AACE. 